
UTAH, AND CASSIA COUNT'Y, IDAHO

(Sections to accompany)

By

Robert R. Compton

\author{
MISCELLANEOUS GEOLOGIC INVESTIGATIONS \\ MAP I-672
}

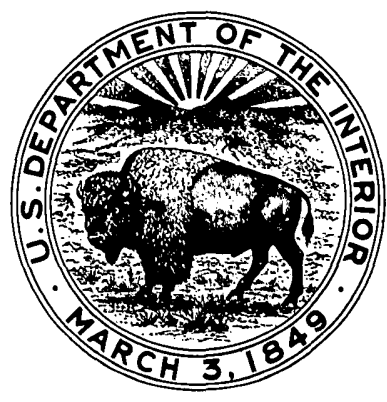

PUBLISHED BY THE U.S. GEOLOGICAL SURVEY WASHINGTON. D.C. 20242 


\section{GEOLOGIC MAP OF THE YOST QUADRANGLE, BOX ELDER COUNTY, UTAH AND CASSIA COUNTY, IDAHO}

By

Robert R. Compton

\section{DESCRIPTION OF MAP UNITS}

The rock units of Yost quadrangle may be divided into two broad categories: Cenozoic sedimentary and volcanic rocks that underlie the wide valleys; and older sedimentary and igneous rocks, now mostly metamorphosed, that form the mountain ranges. The older rocks are Precambrian and Paleozoic in age except for the granitic rocks, which are of unknown age. All of the older rocks were folded and cut by two major thrust faults; nonetheless, they are now mainly subhorizontal, with a structural order that appears also to be their stratigraphic sequence. The units were thinned considerably during metamorphism, as shown by flattened mineral grains that lie parallel to bedding. This thinning has not been taken into account in determining the unit thicknesses reported, which are the present thicknesses, generally measured where the formations are thickest.

\section{QUATERNARY ROCKS}

Modern alluvium.-Sedimentary deposits presently or recently in transit along streams were mapped only where an appreciable flood plain is present and were therefore omitted along the innumerable minor streams. The composition of the modern alluvium is complex and changes greatly from place to place because it has been derived from older alluvial deposits as well as from bedrock slopes. 'Generally, quartzite pebbles and cobbles predominate.

Landslide deposits. - The largest of seven landslides mapped is in upper Junction Valley (sec. 32, T. 13 N., R. 16 W.) and has an areal extent of half a square mile. This slide is younger than the older alluvium; some of the other slides are probably older. An especially interesting slide, exposed 1 mile north of the east end of the Upper Narrows of Raft River, consists entirely of fragments of locally derived schist, some of them many feet across. The deposit is largely covered by older alluvium and locally has the appearance of a thrust sheet lying on the Tertiary tuffaceous sediments.

Older alluvium and contiguous colluvium and fan deposits. The various parts of this composite unit were not separated on the map because they grade into one another. By far the most abundant constituents are alluvial sands, gravels, and silts that have been dissected to depths of as much as 80 feet by the present streams. These deposits are especially well exposed in bluffs along Raft River and Dove Creek, where beds are lenticular, subhorizontal, and cemented locally by old caliche. Compositions vary greatly, but quartzite detritus is generally most abundant. Schist and marble fragments are scarcely more weathered than those in the modern alluvium. Locally, the older alluvium merges upslope with alluvial fans and colluvial aprons, some of which are only slightly dissected. Also included in the map unit are uneroded patches of upland alluvium, such as that in Clarks Basin.

\section{TERTIARY ROCKS}

Tuffaceous sediments and conglomerate.-These rocks are well exposed east and west of Yost, but in most places they are covered by younger gravels or are too friable to crop out Elsewhere in the region similar rocks have been assigned to the Tertiary Payette Formation and to the Salt Lake Formation (Mapel and Hail, 1956), but the Yost quadrangle rocks cannot be correlated with these formations, even tentatively. The section exposed east of Yost is about 8,000 feet thick, and the alluvium under Yost probably conceals an additional several thousand feet of similar beds. Only about 1,000 feet of the rocks are exposed in Junction Valley, but gravity measurements indicate a deep central graben, perhaps filled with similar strata (Cook and others, 1964).

The exposed sections in Yost quadrangle are dominantly tuffaceous, the volcanic component being vitric ash of silicic composition. In the lower part of the section east of Yost, tuffaceous sandstones and siltstones are well lithified and colored various tints and shades of green, yellow, white, and brown. The abundant conglomerates in this part of the section are so poorly sorted and so coarse (1-3 feet) as to suggest torrential deposition on ancient alluvial fans. Up-section there are fewer conglomerate layers, and the tuffaceous silts and sands are friable and white to brown. In Junction Valley, the main sequence consists of friable tan tuffaceous sandstone and siltstone with lenses of pebble conglomerate; the conglomerate and lithified tuffaceous rocks near the base of the section are thin and discontinuous.

Welded dacite tuff.-Remnants of a welded-tuff sheet are exposed locally at the base of the Tertiary sequence in the northwest part of the quadrangle. The rock is similar to tuffs that crop out along the west side of the Albion Range, 12 miles to the north, for which R. L. Armstrong (oral commun., 1969) has obtained a K-Ar age of $8.5 \mathrm{~m} . \mathrm{y}$. The best exposures in Yost quadrangle, near the main road at the west end of the Upper Narrows, show 40 feet or so of brown-weathering, black vitrophyre and gray spherulitic welded tuff that resembles lava. Small phenocrysts of plagioclase and clinopyroxene make up about 5 percent of the rock.

The discontinuous nature of the remnants indicates that considerable erosion took place before the tuffaceous sediments were deposited on them. A different relation is found near Yost; here the tuffaceous sediments project under the lavas and tuffs of the Malta Range, 6 miles to the north (Anderson, 1931). The welded tuff near the Upper Narrows is therefore substantially older than the volcanic rocks of the Malta Range, or the tuffaceous rocks of Junction Valley are younger than those near Yost. In either case, the Tertiary history differed considerably from place to place.

\section{PENNSYLVANIAN ROCKS}

Oquirrh(?) Formation. - Fossiliferous limestone and sandstone similar to rocks of the Oquirrh Formation form numerous klippen in Yost quadrangle. These are remnants of a thrust plate that once extended over the entire area. Neither the upper nor the lower depositional contacts of the unit were found, and the thickest klippe exposes only about 1,000 feet of strata. Nonetheless, most klippen consist of two stratigraphic subunits, the lower mainly of limestone and the upper mainly of sandstone, and a contact was drawn between the subunits in many of the klippen. The limestone-typically dark gray, sandy, and crudely bedded-is interbedded with calcareous 
sandy siltstone and fine-grained orthoquartzite that weather brown or pinkish gray. The sandstone subunit consists mainly of brown-weathering gray orthoquartzite and calcareous sandstone with irregular interbeds of dark-gray limestone. Under the microscope, the sandstone proves to be fine grained and moderately well sorted, and to have many rounded grains. Most of the limestone has many sand-sized fossil fragments in a matrix of fine-grained recrystallized calcite. The rocks are generally unmetamorphosed, but light-gray or pale-tan calcitic and dolomitic marbles occur locally at the base of the klippen of the southern Dove Creek Mountains. Where folded, even the unmetamorphosed rocks have secondary cleavages that may be more apparent than bedding.

Fossil bryozoans, crinoids, and fusulinids are abundant locally but are silicified and too altered to be diagnostic. Fossil material described by Felix (1956, p. 85-86) indicates that most of the rocks are Pennsylvanian.

\section{MISSISSIPPIAN(?) ROCKS}

Metamorphosed Manning Canyon(?) Shale. -Up to 250 feet of dark-gray phyllite with subordinate amounts of gray quartzite and laminated dark-gray marble underlies the thrust plate of Oquirrh(?) Formation in the southern Dove Creek Mountains. Similar rocks form fault slices under the same thrust elsewhere in the quadrangle, but many are too small to show on the map. The phyllite commonly contains small porphyroblasts of chloritoid in a groundmass of quartz, muscovite, chlorite, and graphite. Thin-section study shows that the unit was originally carbonaceous sandy mudstone and poorly sorted sandstone. Lithology and structural position suggest the rocks may be correlative with the Manning Canyon Shale although Stringham (in Stokes, 1963) called the unit Chainman Shale. No fossils were found in the quadrangle, but the same unit on Vipont Mountain, a few miles west of the quadrangle, contains deformed brachiopod shells of unknown age.

\section{ORDOVICIAN(?) ROCKS}

The next three formational units are assigned a probable Ordovician age on the basis of their sequence, position, and intergradational relations. The lowest, a marble, grades upward into pure quartzite, and the quartzite grades into gray dolomite-a succession suggestive of the Pogonip Group, Eureka Quartzite, and Fish Haven Dolomite, and of no other contiguous Paleozoic formations known to the writer. Poorly preserved crinoid and other fossil fragments prove the marble and dolomite to be younger than Precambrian, but are otherwise undiagnostic. Felix (1956) found fossils in the same units in the eastern part of the Raft River Mountains, and noted the resemblance of the marble to metamorphosed Pogonip limestone in Nevada; however, he named the formations Units A, $\mathrm{B}$, and $\mathrm{C}$ of the lower(?) Paleozoic. Stringham (in Stokes, 1963) included the formations in the upper(?) Precambrian Dove Creek Formation.

Metamorphosed Fish Haven(?) Dolomite. - The formation, questionably assigned to the Fish Haven Dolomite, is thickest ( 600 feet) in the Black Hills, on the southern flank of Raft River Mountains, where its succession is (1) several hundred feet of interlaminated silver-gray and dark-gray dolomite; (2) several hundred feet of massive cream-colored dolomite, commonly brecciated; and (3) about a hundred feet of gray laminated dolomite. Elsewhere the unit is represented by only the first subunit.

The grains of the gray dolomite are $0.5-1 \mathrm{~mm}$ in diameter and are interspersed with several percent of muscovite, quartz, and K-feldspar grains. Tremolite porphyroblasts are locally abundant, and white fossil fragments can be seen here and there. The upper part of the formation is in thrust contact with graphitic phyllite or with the Oquirrh(?) Formation.

Metamorphosed Eureka(?) Quartzite. - The Eureka(?) Quartzite is a strikingly white quartzite, 400 feet thick near the cen- ter of the quadrangle but represented by only a few thin lenses in the southern Dove Creek Mountains. Beds are 1 to 6 inches thick and generally discernible at the outcrop even though the rock is thoroughly metamorphosed and completely free of schist interbeds. Sparse muscovite, the only appreciable impurity, imparts a sparkling luster to broken surfaces. Quartz grains average $1 \mathrm{~mm}$ in diameter but cannot be seen without a polarizing microscope. At many places the quartzite is broken tectonically and recrystallized into a remarkably solid nonporous breccia. The unit normally grades into the overlying dolomite through a few feet of interbedded rocks, but a tectonic breccia of quartzite and dolomite commonly lies between the two units.

Metamorphosed limestone of the Pogonip(?) Group. - This unit is as much as 500 feet thick in Yost quadrangle. The lower two-thirds is mainly tan-weathering impure marble characterized by laminations that include numerous $2-$ to $5-\mathrm{mm}$ porphyroblasts of muscovite, biotite (or chlorite), calcic plagioclase, and vesuvianite(?). These larger grains weather into relief against the finer $(0.5 \mathrm{~mm})$ groundmass, which is mainly calcite but includes several percent of dolomite, quartz, and K-feldspar. The upper third of the unit is mainly light gray, nearly pure marble, with grains about $1 \mathrm{~mm}$ in diameter. A layer of pale-brown quartzite, 5 to 20 feet thick, occurs locally in the upper 50 feet of the marble, and in the uppermost 10 to 30 feet, marble is interlayered with white quartzite like that of the overlying formation.

Nearly pure light-gray marble with grains as large as $5 \mathrm{~mm}$ forms thin lenses along the thrust surface under the quartzite of Clarks Basin, and green marble containing abundant epidote and chlorite occur locally near thrusts. Although they are probably metamorphosed Pogonip limestone, some could be limestone of unknown original stratigraphic position emplaced tectonically along the thrusts.

\section{CAMBRIAN(?) ROCKS}

Two formations of quartzite and schist lie conformably beneath the metamorphosed Pogonip(?) Group-a relation that suggests they may be Cambrian. Felix (1956) did not map these units separately, including both in the unit he designated Unit B of the Harrison(?) series, and Stringham (in Stokes, 1963) included both in his upper(?) Precambrian Dove Creek Formation.

Schist of Mahogany Peaks. - A distinctive schist unit, generally 50 to 200 feet thick, is well-exposed near the prominent Mahogany Peaks located near the center of the quadrangle. By far most abundant is dark-brown biotite-muscovite schist with porphyroblasts of garnet and staurolite; locally, the unit includes silvery muscovite schist and graphitic schist, both containing scattered mafic porphyroblasts. Quartz-rich interbeds are so scarce as to indicate that the rock was originally a homogeneous claystone. In the southern Dove Creek Mountains, however, the schist is intricately interlayered with the underlying quartzite where the two were mixed tectonically, and in these places the schist is knobby and silvery green, and consists mainly of chlorite and muscovite. Another tectonic variant occurs along a thrust near Charleston Creek, in the northeastern part of the area, where the unit is entirely phyllitic.

The upper part of the schist is interbedded with the overlying marble along the north side of the Raft River Mountains, where the contact was drawn at the base of the lowest marble. Elsewhere, the contact is sharp and is marked by a few feet of dark-gray graphite-chloritoid-quartz-muscovite schist.

Quartzite of Clarks Basin. - This unit is well represented around Clarks Basin, an upland valley near the center of the quadrangle, where it is about 400 feet thick. The quartzite is characterized everywhere by distinct thin beds separated by very thin but rather coarse-grained muscovite schist layers that are impressed on the surfaces of loose slabs of quartzite flagstone as oval shiny patches. The lower contact was drawn at the base of the lowest quartzite in the sequence-typically a 
medium-gray nonfeldspathic quartzite in layers 1 to 3 inches thick. In most places, this quartzite is overlain by 10 to 40 feet of schist like that of the underlying unit (schist of Stevens Spring), and then by essentially continuous quartzite, the lower two-thirds of which is gray to pale orange, contains 5 to 15 percent of $\mathrm{K}$-feldspar, and includes a few beds 2-3 feet thick among the thinner beds. The remaining (upper) part of the formation is white or light gray, nonfeldspathic, and in beds no thicker than 3 inches. The contact with the schist of Mahogany Peaks is sharp and apparently conformable. All the quartzite in the unit contains a.few percent of muscovite; the schist interlayers locally contain macroscopic kyanite, chloritoid, or biotite.

\section{PRECAMBRIAN(?) ROCKS}

Metamorphosed shale and sandstone that appear to lie conformably beneath the quartzite of Clarks Basin make up a subhorizontal sequence that is exposed over much of Yost quadrangle as well as for many miles to the east in the Raft River Mountains. In the quadrangle, the sequence averages 1,500 feet thick and consists of four formational units that are genetically related. All were included in the unit that Felix (1956) named Unit B of his Harrison(?) series, and the upper three were included by Stringham (in Stokes, 1963) in his upper(?) Precambrian Dove Creek Formation. The basal formation has been mapped into the southern part of the Albion Range, where it was mapped and named the Elba Quartzite by Armstrong $(1968$, p. 1301). The remaining three formations may be equivalent to the lower part of Armstrong's (1968, p. 1301-1302) Conner Creek Formation, but this correlation must be tested further.

Armstrong (1968) considered the Elba Quartzite to be Cambrian(?) and the Conner Creek Formation to be Cambrian or Ordovician; however, the Rb-Sr data cited by him permit rather than require these age assignments (Armstrong and Hills, 1967), and the fossiliferous Conner Creek described by him is similar to units in Yost quadrangle that are younger than the four formations considered in this section. A probable late Precambrian age is indicated for these four formations by certain distinctive rocks that are not known to occur in the Cambrian or Ordovician formations of the region, specifically: green quartzite, magnetite-rich and hematite-rich rocks, metadiabase, metamorphosed granite porphyry, and metamorphosed silicic tuffs and tuffaceous sedimentary rocks.

Schist of Stevens Spring. - The youngest late Precambrian(?) formation is a fine-grained schist exposed near Stevens Spring, 6 miles south of the village of Yost. The unit is 500 feet thick in the southwestern part of the quadrangle and about 300 feet elsewhere. Exposures are far poorer than those of the overlying and underlying quartzites. The main rock is fine-grained muscovite-quartz schist that contains abundant lenses of graphitic phyllite 0.5 to 2 inches across and 0.1 inch thick-apparently carbonaceous laminae that were disrupted tectonically. These rocks are interlayered with homogeneous muscovitic and graphitic phyllites and schists, some with garnet or chloritoid porphyroblasts. On the south side of the Raft River Mountains, the lower part of the formation is fine-grained biotitemuscovite-quartz schist. Dark-green satiny epidote-hornblende schist and plagioclase-hornblende schist form layers as much as 10 feet thick that occur locally throughout the quadrangle and are especially common near the top of the formation in the Dove Creek Mountains. Metadiabase with relict igneous texture forms a 30 -foot sill in the upper part of the unit in upper Johnson Creek Canyon, and smaller bodies of metadiabase occur elsewhere. Almost every well-exposed section shows one or two subunits of feldspar-rich muscovitic quartzite, each only a few feet thick. These were almost certainly rhyolite tuffs or tuffaceous sediments.

Quartzite of Yost. - A unit of quartzite approximately 400 feet thick is well exposed in the Raft River Mountains due south of the village of Yost. The formation thins to 200 feet in the northwest and central parts of the quadrangle and pinches out in the southwest part. The upper contact is either sharp or grades rapidly from quartzite to the schist of Stevens Spring. The quartzite is characteristically white, sparsely to moderately muscovitic, and in beds a foot or less thick. Strikingly green quartzite, colored by chromian mica, occurs in the Upper Narrows in the northwest part of the area, and palegreenish-gray variants can be found elsewhere. Magnetiterich quartzites and hematitic schists form thin layers in the northwest part of the quadrangle. Some of the thicker beds along Johnson Creek contain small quartz pebbles and coarse grains of $\mathrm{K}$-feldspar. Beds in the central part of the quadrangle contain as much as 10 percent of $\mathrm{K}$-feldspar.

Schist of the Upper Narrows. - This unit is fully exposed in the steep-walled canyon called the Upper Narrows of Raft River, in the northwest part of the quadrangle. The unit is thickest, perhaps 1,500 feet, a few miles south of the Upper Narrows; from here it thins rapidly to the south and pinches out in the southern part of the quadrangle. Except for a muscovitequartz schist member that has been mapped separately, the formation is characterized by dark-brown or gray rocks that form large slabby outcrops. Most abundant are fine- to medium-grained biotitic schist and fine-grained gneiss that contain appreciable quartz, K-feldspar, plagioclase, and muscovite. The gneiss and medium-grained schist commonly carry segregated quartz or quartz-feldspar lenses averaging an inch thick and a few feet across. In the upper part of the unit, thin phyllitic layers have been separated tectonically into dark-gray or silvery lenses measuring 1-2 inches across and 0.1 inch thick, which give the outcrops a patchy appearance. Garnet porphyroblasts are present locally, as are thin layers of quartzite. Small bodies of amphibolite (metadiabase) crop out in the Upper Narrows, and schists with considerable calcite or amphibole occur in the upper part of the formation here and elsewhere.

The muscovite-quartz schist member forms an extensive lens, roughly 500 feet thick at its center, in the northern Dove Creek Mountains. The silvery gray to light-tan rocks contain 20 to 40 percent of muscovite and locally appreciable K-feldspar, chiefly as large relict grains. The schist appears to have been bedded but differs so markedly from the adjoining dark schist as to suggest it was a separate body of rhyolite tuff or tuffaceous sedimentary rock. The upper contact of this member is nowhere exposed, and the stratigraphic relations in the upper part of the formation in the Dove Creek Mountains are confused by complex folding. The member is missing in the Raft River Mountains, where the main dark schist is overlain by the quartzite of.Yost along a sharp contact.

Elba Quartzite. - The Elba Quartzite, named by Armstrong $\left(1968\right.$, p. 1301) for exposures at its type section in $S^{1 / 2}$ sec. 1 , T. 14 S., R. 24 E., west of the town of Elba, Idaho, forms the most striking outcrops in Yost quadrangle. The white and tan dip slopes and cliffs of this quartzite characterize the Raft River Mountains and parts of the Dove Creek Mountains and the Grouse Creek Mountains. The formation is as much as 1,500 feet thick in the northwestern part of the quadrangle and no more than 50 feet thick near the center, averaging 500 feet over most of the area. Where the unit is thicker than average, most beds are 1 to 8 feet thick many are crossbedded on a large scale, and a few contain well-sorted quartzite-pebble conglomerate. Where the formation is no thicker than average, beds are rarely more than a few feet thick and much of the unit is thin bedded, even flaky and semischistose. The quartzite is white or pale tan, or very locally green. The tan pigment is residual to leached dolomite grains, which commonly formed distinctive ovules an inch or so long. These bodies were flattened and lineated tectonically, as were quartzite pebbles in conglomerate layers. Some of the white quartzite is nearly pure but most contains a few percent of muscovite, dolomite (or tremolite and diopside after dolomite), and sparse K-feldspar. Muscovite-quartz schist forms thin layers between some 
of the beds. Except for the conglomerates, the rocks are too metamorphosed to show original grains, but their purity indicates well-sorted mature quartz sands.

The formation grades upward through 10 to 100 feet of biotite-muscovite quartzite into the overlying unit-a relation especially well exposed in the Upper Narrows of Raft River. Although the Elba Quartzite was designated Cambrian(?) by Armstrong (1968, p. 1298), it is here considered late Precambrian(?) for reasons presented under the heading Precambrian(?) rocks.

\section{PRECAMBRIAN ROCKS}

Older schist. - Brown and silvery mica-rich schists, originally shales and sandstones, are apparently the oldest rocks in the quadrangle. Intruded by granitic bodies, they form extensive remnants as much as 300 feet thick along the borders of the granitic intrusions and also occur as inclusions in them. In the eastern part of the quadrangle, both schist and granite appear to be overlain unconformably by the late Precambrian(?) Elba Quartzite; however, the metamorphism of all the units makes this relation difficult to interpret. The unit consists of muscovite-biotite-quartz schist, mica-plagioclase-microcline-quartz schist, and muscovite-quartz schist. These rocks are lithologically similar to thicker and more extensive schist remnants in the eastern part of the Raft River Mountains, where they have been intruded by granitic rocks that have been dated provisionally as early Precambrian by R. E. Zartman (written commun., 1969). The schists there were named Unit A of the Harrison(?) series by Felix (1956), but no detailed correlations have been made between the Raft River Mountains and the Albion Range, where the Harrison Series was first described by Anderson (1931). R. L. Armstrong (written commun., 1969) noted the similarity of the older schist to Albion Range schists dated at $2.46 \pm 0.3$ billion years or older (Armstrong and Hills, 1967, p. 119).

\section{INTRUSIVE IGNEOUS ROCKS}

Metamorphosed adamellite. - Granitic rocks of undetermined age are exposed in all the more deeply eroded parts of the area and may well be present at moderate depth throughout the quadrangle. Two or more intrusive bodies are present, but because they were metamorphosed dynamothermally the usual igneous features could not be used to subdivide them in the time available. The principal rock in all the mapped exposures is metamorphosed adamellite, locally accompanied by granodiorite. All the rocks contain at least a few K-feldspar phenocrysts, and some are crowded with them. Rock textures were so affected by metamorphism that they vary greatly with depth. The deepest exposures show moderately foliated and lineated rocks; these grade upward into a zone of gneiss with feldspar augen; and the gneiss grades upward into a zone of schist, 10 to 100 feet thick, containing small ovoid relics of the large feldspar grains. In all the rocks, foliation and lineation are imparted by the shaped feldspar grains and by flattened and elongated aggregates of muscovite and biotite, some of which are secondary to garnet grains. The lineations are typically parallel to fold-axis lineations in the overlying metamorphic rocks, indicating that all the granitic rocks were emplaced before or during metamorphism.

Intrusive relations indicate that the youngest of the granitic rocks occur in the western part of the quadrangle. In Muddy Canyon, at the south edge of the quadrangle, dikes can be traced from the main adamellite body into the Elba Quartzite, and inclusions of the quartzite occur nearby in adamellite. At the west end of the Upper Narrows of Raft River, and in another locality 2.5 miles south of the center of the quadrangle, large granitic dikes are intrusive into the upper Precambrian(?) units. On Vipont Mountain, 4 miles west of the northwest corner of the quadrangle, lineated granodiorite and adamellite intruded the Cambrian(?) and Ordovician(?) formations, and Rb-
Sr determinations on a suite of samples from this locality indicate a probable early Tertiary age (R. E. Zartman, written commun., 1969).

Evidence that some granitic rocks are older is somewhat more equivocal, but those in the eastern part of the quadrangle appear to lie unconformably beneath the Elba Quartzite. This relation is best shown in Corner Creek Canyon, on the south flank of the Raft River'Mountains, where the Elba Quartzite lies with angular discordance across a steep contact between adamellite and older schist. It seems contrary that just to the east in Century Hollow the adamellite appears to include a large xenolith of quartzite, but this could be an older quartzite that originally lay beneath the older schist. Preliminary $\mathrm{Rb}-\mathrm{Sr}$ determinations on adamellite and granodiorite 7 miles east of the quadrangle indicate an early Precambrian age (R. E. Zartman, written commun., 1969), and this could well be the same body as that exposed in Corner Creek Canyon.

In summary, at least some granitic rocks in the western part of the quadrangle are younger than the Elba Quartzite, and some in the eastern part of the quadrangle are older. All were emplaced before or during dynamothermal metamorphism, which deformed the upper parts of the bodies much more than the lower parts.

Metamorphosed granite porphyry. - A fairly extensive body of granite porphyry is exposed in Road Canyon, in the southern Dove Creek Mountains, where it lies between the schist of the Upper Narrows and the schist of Stevens Spring. Small lenses and dikes of the same rock have been mapped in about the same stratigraphic position for 2 miles to the south; and thin layers and lenses of similar rocks, often associated with feldspathic quartzites, occur widely in the schist of Stevens Spring. The porphyry is typically schistose, with relics of feldspar phenocrysts and variable proportions of biotite and muscovite. The mapped bodies have sharp boundaries, but some others grade to quartzites, as though they might have been tuffs. The mapped unit is probably a suite of hypabyssal intrusive rocks genetically related to volcanic rocks in the schist of Stevens Spring, although it could conceivably be much younger.

\section{STRUCTURE}

Although the formations are subhorizontal over large areas, they have undergone several episodes of deformation, including metamorphic flowage, folding, thrusting, and high-angle faulting. The first two episodes probably took place during the Cretaceous and early Tertiary, and resulted in metamorphic flowage and consequent thinning of the Paleozoic and older units, locally forming nearly recumbent folds of large size. Two major décollement-type thrusts developed at about the same time, one lying at the base of the Oquirrh(?) Formation and the other near the base of the Paleozoic sequence. Another episode of folding took place after metamorphism, accompanied and followed by more thrusting; however, the direction of transport was markedly different from those of the earlier episodes. Following the last thrusting, the area was pressed into broad anticlines and synclines that were subsequently broken along normal faults, some of which have been active recently.

Folds - The characteristics of the older folds suggest solidstate flowage during metamorphism. They tend to be strongly overturned, to extend along strike for only a few miles or less, to have curved axial lines, and to show marked thinning of units on their gently inclined limbs. Folds with amplitudes greater than a foot occur only locally, but microfold lineations are widespread and are coaxial with elongate pebbles and metamorphic mineral grains. These folds can be divided into two major generations on the basis of refolded lineations observed at many outcrops. Folds of the first generation are developed mainly in the lower Precambrian and upper Precambrian(?) units, and their distribution and various trends are shown in figure 1. In almost all cases they are overturned toward the 
northwest and west. The second generation of folds and metamorphic lineations is developed equally in Paleozoic and older rocks. These folds are overturned toward the northeast and cross the older folds at various angles (fig. 1).

A third generation of folds started to form during the closing stages of metamorphism but is mainly postmetamorphic. It is represented locally by large folds in the Paleozoic units and by small corrugations in the older rocks. Axial trends are approximately north-south, and the larger folds are overturned strongly toward the east (fig. 2). The principal folds in the Oquirrh(?) Formation have this same trend but are not markedly overturned. The latter folds are cut off at the thrust fault underlying the Oquirrh(?) and must therefore have formed before the plate was fully emplaced.

Following thrusting, all the units and structures were deformed into widely spaced open symmetrical folds with limbs that typically dip $15^{\circ}$ to $20^{\circ}$. The largest of these, the anticline that forms the Raft River Mountains, trends east-west for a distance of 22 miles, dying out at the west against the main north-south anticline of the Dove Creek Mountains, near the center of Yost quadrangle (fig. 2). Judged from relations seen at the east end of Raft River Mountains, the north-south folds are the older, but this cannot be proved in Yost quadrangle.

Fuult: - Oldest and most extensive of the faults are the lowangle thrusts that divide the sequence into two principal thrust plates and an autochthon. The upper plate is deeply eroded and now consists only of the Oquirrh(?) Formation but probably once included younger strata. The lower plate extends from the top of the metamorphosed Manning Canyon(?) Shale down to a thrust that typically lies near the base of the quartzite of Clarks Basin or the top of the schist of Stevens Spring-a vertical distance ranging from nearly 0 to 2,000 feet and averaging 800 feet. Subsidiary thrusts divide the lower plate into several subparallel wedges, and the lenses of phyllite at the top of the plate are bounded entirely by thrust surfaces. Sheets of breccia or phyllonite are rarely seen along any of the thrusts, but the faults can be recognized where (1) beds are cut off by the underlying thrust, (2) older units overlie younger units, (3) overturned units lie directly on older upright units, and (4) formations are missing or are represented by minor slices. The complete absence of Silurian, Devonian, and most Mississippian units implies a major décollement-type fault at the base of the upper plate, and decollement faulting is also indicated by the tendency for younger units to be emplaced on older, and for the fault surface to lie along or near unit contacts.

Useful in determining directions of the latest thrusting are two high-angle strike-slip faults, one in the Black Hills and one east of Clarks Basin. These faults indicate that the lower plate was divided into steep-sided tongue-shaped bodies during a late stage of thrusting. Offsets on the faults indicate eastward thrusting near Clarks Basin and northeastward thrusting in the Black Hills, and sets of imbrications in the two areas indicate the same directions of movement.

The imbrications in the Black Hills carried lower-plate Paleozoic rocks over the Oquirrh(?) Formation of the upper plate and indicate several miles of displacement on the lower thrust after the upper plate was emplaced. There is no direct measure of earlier displacements, but the greatly abbreviated stratigraphic section beneath the Oquirrh(?) plate indicates that it has traveled far. The structural truncation at the lower thrust appears to require far less movement; however, the Cambrian(?) sequence is so atypical for the region as to suggest largescale displacement. The coarsely recrystallized tectonic marble along the lower thrust indicates that much of this thrusting took place before or during metamorphism.

All the normal faults are much younger than the thrusts, for they cut the late Tertiary folds that deformed the thrusts. They strike in two preferred directions, N. $20^{\circ} \mathrm{W}$. and N. $30^{\circ}$ $\mathrm{E}$., and their zigzag and branching traces and their steep basinward dips are similar to those of other faults of the Basin and
Range province. The faults along the east side of the Dove Creek Mountains locally displace colluvium, but many of the other normal faults have been eroded deeply since they formed.

\section{ECONOMIC DEPOSITS}

Metals. -Judged chiefly from reports by Higgins (1909) and MacFarren (1909), approximately $\$ 500,000$ worth of gold has been produced from quartz veins in Century Hollow and vicinity, on the south flank of the Raft River Mountains. Ore tenor ranged from $\$ 8$ to $\$ 100$ per ton in gold. The veins strike between east and northeast, and although they dip steeply they lie entirely within the granite. All production was from native gold in the upper parts of the veins, where primary iron sulfides were oxidized. Galena and high silver concentrations were found locally. Most of the gold was produced before 1913 and the mines have been virtually inactive since about 1934 .

On the north side of the Raft River Mountains, several prospects have been opened along the lower reaches of Wildcat Creek, Johnson Creek, and Charleston Creek. The mineralized materials are quartz veins and lenses as well as associated schist and quartzite. The ore minerals appear to be galena and iron sulfides, and values are said to be mainly in silver and locally in gold. Production is unknown but probably small.

Quartzite. - Unusually handsome and durable flagstone has been quarried from the quartzite of Clarks Basin at a number of places. The Elba Quartzite and the quartzite of Yost have also been worked for flags and ornamental broken stone, and the metamorphosed Eureka(?) Quartzite has been quarried for ornamental aggregate. It would appear from the map that flagstone could be quarried at countless localities; however, the rocks are commonly too folded or fractured to be of value.

\section{ACKNOWLEDGMENTS}

Although I have mapped the entire area, the Stanford summer field class of 1965 mapped about half of it and worked out many of the structural and stratigraphic problems. Max Crittenden, Ralph Roberts, and Lowell Hilpert provided helpful suggestions during the course of the study, and the Forest Service, the Bureau of Land Management, and many ranchers helped me in various ways. Bronson Stringham and Richard Armstrong kindly supplied preliminary copies of maps. My son Andrew assisted me during the 1966 season, and Victoria Todd contributed data from studies made south of the area. Clark Blake and Edwin Tooker read the manuscript and suggested many improvements.

\section{REFERENCES CITED}

Anderson, A. L., 1931, Geology and mineral resources of eastern Cassia County, Idaho: Idaho Bur. Geology and Mines Bull. 14, $169 \mathrm{p}$

Armstrong, R. L., 1968, Mantled gneiss domes in the Albion Range, southern Idaho: Geol. Soc. America Bull., v. 79, no. 10, p. 1295-1314.

Armstrong, R. L., and Hills, F. A., 1967, Rb-Sr and K-Ar geochronologic studies of mantled gneiss domes, Albion Range, southern Idaho, USA: Earth and Planetary Sci. Letters, v. 3, no. 2, p. 114-124.

Cook, K. L., Halverson, M. O., Stepp, J. C., and Berg, J. W., Jr., 1964, Regional gravity survey of the northern Great Salt Lake Desert and adjacent areas in Utah, Nevada, and Idaho: Geol. Soc. America Bull., v. 75, no. 8, p. 715-740.

Felix, C. E., 1956, Geology of the eastern part of the Raft River Range, Box Elder County, Utah, in Eardley, A. J., and Hardy, G. T., eds., Geology of parts of northwestern Utah: Utah Geol. Soc. Guidebook to the geology of Utah, no. 11, p. 76-97.

Higgins, W. C., 1909, The Century and the Susannah mines, Golden, Utah: Salt Lake Mining Review, v. 11, no. 16, p. 19-22.

MacFarren, H. W., 1909, The Park Valley mining district of Utah: Salt Lake Mining Review, v. 11, no. 7, p. 17-18. 
Mapel, W. J., and Hail, W. J., Jr., 1956, Tertiary stratigraphy of the Goose Creek district, Cassia County, Idaho, and adjacent parts of Utah and Nevada, in Eardley, A. J., and Hardy, G. T., eds., Geology of parts of northwestern Utah: Utab
Geol. Soc. Guidebook to the geology of Utah, no. 11 p. 1-16. Stokes, W. L., 1963, Geologic map of northwestern Utah: Utah Univ., Coll. Mines and Mineral Industries, scale 1:250,000.

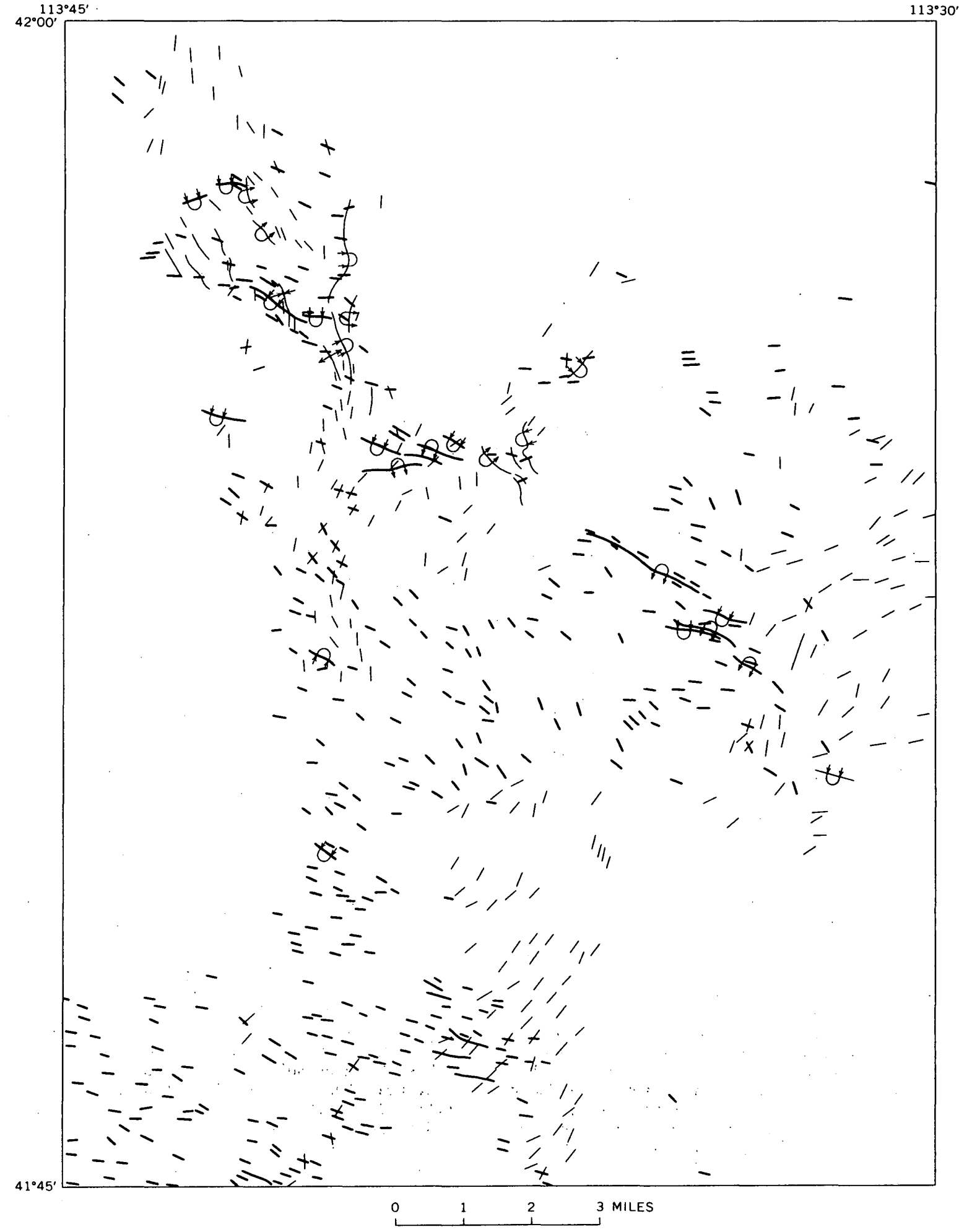

FIGURE 1. Map of Yost quadrangle showing trends of first-generation folds and metamorphic lineations (thin lines), and second-generation folds and metamorphic lineations (heavy lines). 


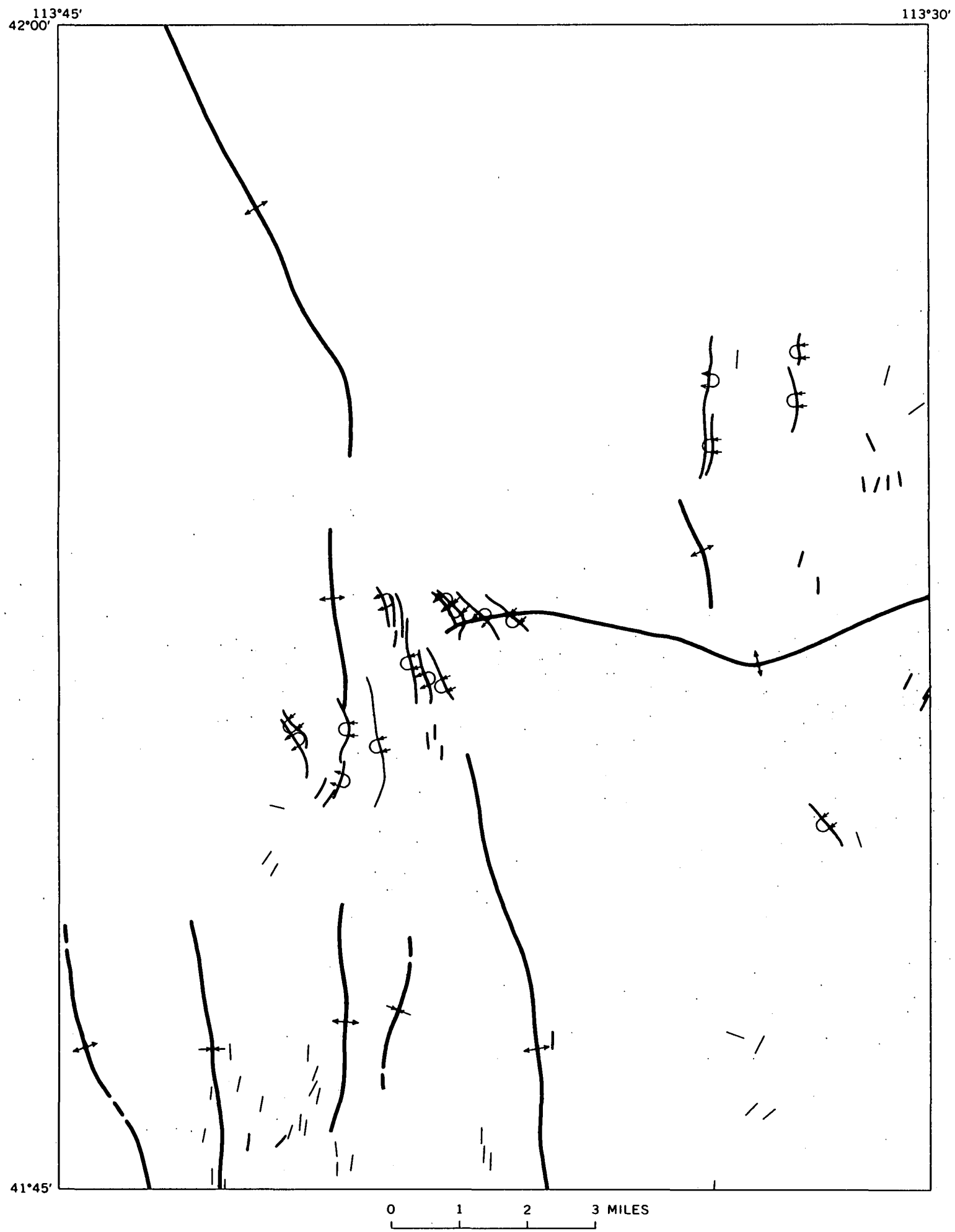

FIGURE 2. Map of Yost quadrangle showing trends of folds in Oquirrh(?) Formation. (medium lines), third-generation folds in rocks older than the Oquirrh(?) Formation (thin lines), and late tertiary folds (heavy lines). 